\title{
＜合同シンポジウム >
}

\section{高血圧・脳卒中の遺伝子疫学}

\author{
檜坦 實男 杉本 研* 勝谷 友宏* 荻原, 俊男 \\ 愛媛大学医学部第二内科, *大阪大学大学院加企医学
}

Key words : 遺伝子, 高血圧, 脳血管障害, 脳卒中

(脳卒中 $24: 513-518,2002$ )

\section{はじめに}

ゲノムプロジェクトの展開によって, 循環器病の発 症メカニズムが個人の持つ遗伝子と環境の相互作用か ら解明されようとしている。このような研究では大規 模な遺伝疫学的手法が必要であり, 詳細な生活暦の収 集と多数 DNA 検体の大量高速（ハイスループット)解 析が必須である。本態性高血圧症では既にレニン一ア ンジオテンシン系遺伝子を中心に数多くの高血圧遺伝 子が発見されているが，なかでもアンジオテンシノー ジェン遺伝子多型と食塩感受性の関係が注目されてい る.すなわちアンジオテンシノージェン遗伝子の T235 アリルは高血圧の遺伝的なリスクであるが, その作用 の強弱は個人の食塩椇取量に依存し, 減壏食に上る降 压効果も本遺伝子型の者では強い。アンジオテンシ ノージェン T235アリル頻度は日本人では $80 \%$ 近く にも上り，遺伝子から見ると「日本人は高血圧人」で あると言える。一方, 高血圧とは独立した脳卒中のリ スク遗伝子が多数発見されている. その多くのものは 血液凝固系の遺伝子であるが，レニン一アンジオテン シン系遺伝子も脳卒中に深く関わっていることが明ら かにされている，我タが大阪地区内の病院，および東 北大学, 今井 潤教授と共同で行った遺伝子疫学研究 (大迫研究)では，アンジオテンシン変換酵素遺伝子 $\mathrm{DD}$ 型多型とアンジオテンシン II タイプ 1 受容体遺伝 子 $\mathrm{A} 1166 \mathrm{C}$ 多型が有意な脳梗塞リスクであることが明 らかにされたささらに脳梗塞発症においてアンジオテ ンシノージェン遺伝子とアンジオテンシン変換酵素遺 伝子にリスクの相乗効果が存在することも明らかに なった.これらの研究は高血圧・脳卒中の成因解明に 止まらず，その予防策の立案にも有用と考えられてい る.

\section{I. 高血圧の遺伝子解析}

ヒトの遺伝子 (ゲノム) には無数の遺伝子多型 (gene polymorhisms）が認められる. 近年, この多型によっ て “生来の体質”ととらえられてきた個人の疾患感受 性を説明できることが明らかになった．高血圧をはじ めとした多因子病 (multifactorial disease) の素因も遺 伝子多型を用いた解析から解明されつつある. その方 法論として，既に高血圧の成因に関与している可能性 が高いと考えられていた物質に関して，その遺伝子を 逐次検討してゆく候補遗伝子アプローチ（candidate gene approach) が進んでいる(表 1) ${ }^{1}$.一方，ほぼシー クエンスが明らかにされたヒトゲノムの構造の個人差 から，SNPs マップと言われる地図を基準に高血圧と 連鎖する座位を機械的に決定してゆくゲノムワイドス キャン（genome-wide scan）も進行している.

これらの研究によって, 現時点で, 水・電解質代謝 ホルモン(レニン・アンジオテンシン系, Na 利尿ペプ チド系，ステロイド代謝酵素など)，交感神経系(交感 神経 $\beta$ 受容体など)，インスリン抵抗性関連(インスリ ン受容体，LDL 受容体など), 電解質チャンネル関連 (アデュシンなど)の遺伝子が高血圧候補遺伝子として 報告されている．血圧上昇に関与する遺伝子とその変 異部位が同定されれば，この変異がどのような遺伝子 機能変化を引き起こして高血圧を生じるかを解明しな ければならない.これまでの研究では, (1)プロモーター 領域の変異による転写充進(アンジオテンシノージェ ン，プロスタサイクリン合成酵素)，(2)サイレンサー様 機能配列を持つヒ卜型 Alu 配列の欠失（アンジオテン シン変換酵素)。(3)受容体のアミノ酸変化による活性化 $\left(\beta_{2}\right.$ アドレナリン受容体のアップレギュレーション， アンジオテンシン II 受容体のG 蛋白親和性の変 化?）などの例が報告されている. 
表 1 本態性高血㾏症の候補遗伝子

\begin{tabular}{|c|c|c|c|}
\hline 染色体座位 & 媊伝子名 & 染色体座位 & 遗伝子名 \\
\hline $1 \mathrm{p} 36.2$ & ANP & $11 \mathrm{p} 15.5$ & チロシン水酸化酵素 \\
\hline $1 \mathrm{q} 32$ & レニン & $12 \mathrm{p} 13$ & $\mathrm{G}$ 蛋白 $\beta 3$ サブユニット \\
\hline $1 q 42-q 43$ & アンジオテンシノージェン & $16 p 13.11$ & SAH（Acyl-CoA 合成酳素） \\
\hline $3 q 21-q 25$ & $\mathrm{AT}_{1}$ 受容体 & 16p13-p12 & $\mathrm{Na}$ チャンネル $\beta$ サブュニット \\
\hline $4 \mathrm{p} 16.3$ & $\alpha$ アデュシン & $17 \mathrm{q} 23$ & $\mathrm{ACE}$ \\
\hline $5 q 31$ & グルココルチコイド受容体 & $17 \mathrm{q} 25$ & グルカゴン受容体 \\
\hline $5 q 32-q 34$ & B 2 受容体 & $19 \mathrm{p} 13.2$ & インスリン受容体 \\
\hline $7 p 15-p 13$ & グルコキナーゼ & $19 p 13.2-13.1$ & LDL 受容体 \\
\hline $7 \mathrm{q} 36$ & eNOS & $19 \mathrm{q} 13.3$ & グリコーゲン合成酵素 \\
\hline $8 \mathrm{p} 22$ & LPL & $19 \mathrm{q} 13.3$ & $\mathrm{PGI}_{2}$ 合成䣼素 \\
\hline 8p12-p11.2 & B3 受容体 & $19 \mathrm{q}$ & カリクレイン \\
\hline $8 \mathrm{q} 21$ & アルドステロン合成酜素 & $\mathrm{Xq} 22-23$ & $\mathrm{AT}_{2}$ 受容体 \\
\hline $10 \mathrm{q} 24-\mathrm{q} 26$ & $\alpha 2$ 受容体 & & \\
\hline
\end{tabular}

各種の高血圧遺伝子の中でも最も重要と考えられて いるのが, 水・Na代謝を司る昇圧ホルモン, レニン・ アンジオテンシン系の遺伝子である. レニン一アンジ オテンシン系遺伝子に関しては，ゲノムワイドスク リーニングによる解析結果からも, 高血圧との関与が 示唆されており，本遺伝子の高血压に対する関与がさ らに強く支持されている．なかでもアンジオテンシ ノージェンはレニン・アンジオテンシン系カスケード の出発物質で, その血中濃度は血圧値と相関すること も報告されている。アンジオテンシノージェン遺伝子 の発現に最も重要なコアプロモーター領域にはA $(-20) \mathrm{C}, \mathrm{C}(-18) \mathrm{T}, \mathrm{A}(-6) \mathrm{G}$ の 3 多型が存在し ており，そのタイプによってコアプロモーター結合転 写開始因子との結合度が变化して, 遺伝子の転写が立 進し，高血圧になることが明らかにされた2゙。これらの 多型は従来からアンジオテンシノージェン遗伝子の高 血圧マーカーとされてきた第 2 エタソンの M235T 多 型と連動している(強い連鎖不平衡)ことから，M235 T多型はコアプロモーター部分の遺伝子型を示すマー カーであったことも明らかになった。この M235T多 型の高血圧タイプ遺伝子型（T235）の頻度は，黑人， 日本人, 白人の順に高く, 体内に水·食塩を眝め易い 食塩感受性の本遺伝子型が環境に適応して隇少してき たと考えても良いだろう。さらに人類と同じ祖先から 分岐した類人猿は総て $\mathrm{T} 235$ 型と報告されていること から, T235 型は人類の誕生以前加存在していた生存 に有利な遺伝子型（shrifty genotype：佮約遺伝子 型)であったと考えられている3．次いで，アンジオテ
ンシン変換酵素 $(\mathrm{ACE})$ 遺伝子にはその第 16 イントロ ンにAlu（アルー）配列と呼ばれる特殊な配列が挿入 （Insersion）または欠失 (Deletion) する ID 多型が存在 している.アンジオテンシン変換酵素遺伝子の DD 型 はこれまでに，高血圧，心筋梗塞，緊急経皮的冠動脈 掂張術後 (PTCA) 後再狭窄, $\operatorname{IgA}$ 腎症など各種循環器 疾患の予後悪化因子として報告されている。またアン ジオテンシン II タイプ1受容体 (AT1) 遺伝子につい ては $\mathrm{A} 1166 \mathrm{C}$ 多型が研究されている。これまでの研究 から AT1 A1166C 多型は白人では本態性高血圧症の 遺伝危険因子になるとの報告が多いが，日本人では全 く関連が認められていない.C1166アリルの頻度は白 人で $25 \%$ あのに対し，日本人では $10 \% ，$ 黒人では 5\%に過ぎず，日本人や黒人においてCC型は非常に 稀であることが検出力を低下させているのかもしれな い。一方，我々は $\mathrm{A} 1166 \mathrm{C}$ 多型のCアリルが，心肥大 やラクナ梗塞の独立したリスクとなることも証明して いる".

\section{II. 脳卒中の遺伝子解析}

高血圧は脳卒中の最大のリスクであるが，脳卒中そ のものもいくつかの遺伝的リスクとなる多型が報告さ れている(表 2).

a. レニンーアンジオテンシン系

水・Na 代謝を司るレニン一アンジオテンシン系の 出発物質，アンジオテンシノージェンの遺伝子には $\mathrm{M}$ 235T と呼ばれる多型が存在している.またアンジオテ ンシン変換酲素 (ACE) 遺伝子には Alu 配列の抻入/欠 
表 2 脳卒中のリスク遗伝子

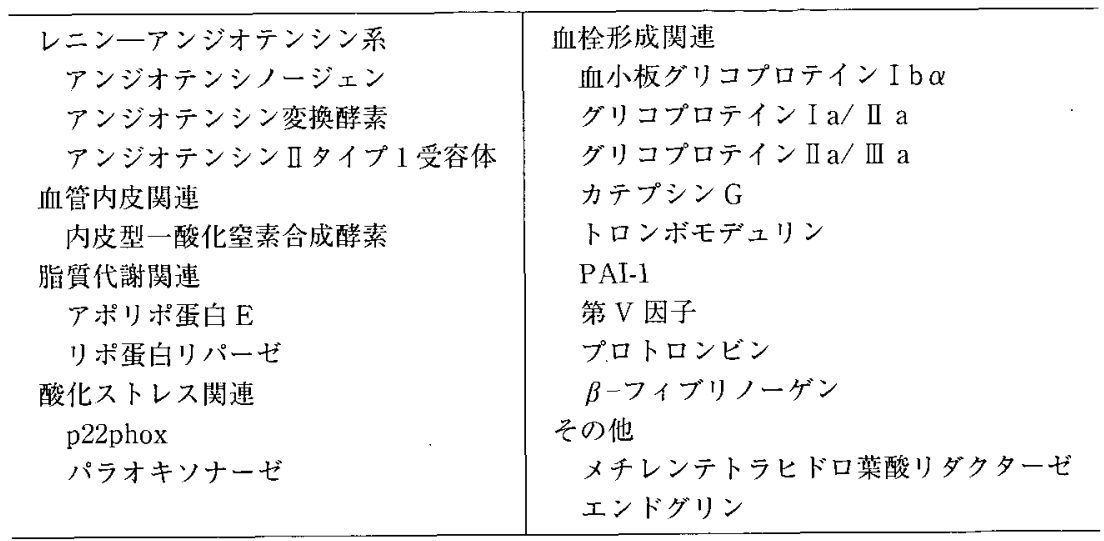

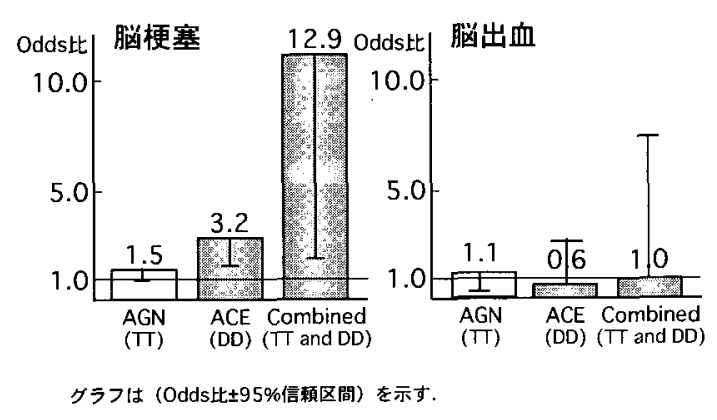

图 1 脳空中の遗伝的相対危険度 阪大・関連 4 病院研究

失多型が存在する．欠失型ホモである DD 型は単独で ラクナ梗塞 $\mathrm{ACE}$ の DD 型とアンジオテンシノージェン TT型の 間には遺伝子リスクの相乗作用が認められ，このよう な人は極めて脳梗塞のリスクが高くなることが明らか になっている。な怙興味深いことに脳出血ではこのよ うなリスクの相乗作用は認められなかった（図 1) ${ }^{6}$.

一方, アンジオテンシン II タイプ 1 受容体 (AT1) 遺 伝子には $\mathrm{A} 1166 \mathrm{C}$ 多型があり，これも脳梗塞との関係 が調心゙られている．我々が東北大学医学部之共同で 行った大迫研究でも，1166Cアリルの存在はラクナ梗 塞と PVH（paraventricular hyperintensity）と関連す ることが示されていた $(\text { 図 } 2)^{7}$.

b. 血管内皮機能異常を引き起こす遺伝子

内皮型一酸化空素合成酵素 (eNOS) は, 一酸化窒素 （NO）を介した血管内皮機能の調節や動脈硬化に重要
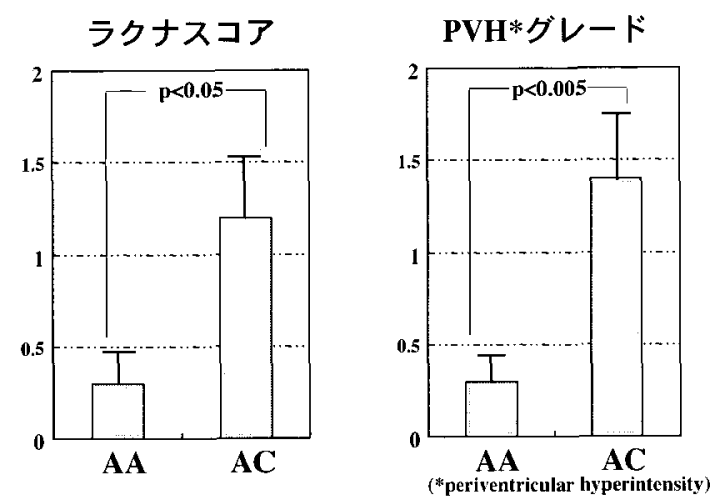

図2 $\mathrm{AT}_{1} / \mathrm{A} 1166 \mathrm{C}$ 多型とラクナ梗塞 大迫研究：MRI 施行 134 人

な役割を果たしている．eNOS 遺伝子には Glu298Asp 多型が存在しており, 脳梗塞群でAsp/Asp 型がコン トロールよりも高頻度に認められ, ラクナ梗塞も $\mathrm{Asp} / \mathrm{Asp}$ 群で高頻度に認められたとの報告がある゙.

c. 脂質代謝に関連する遺伝因子

アポリポ蛋白 E (APOE) 遺伝子には e2, e3,e4のア リルが存在し，おのおの表現型 E2, E3, E4に対応して いる. e2アリルを持つ群は, e3/e3 型を持つ群に比し に比し脳卒中のリスクが有意に高く, e2/e2 型では脳 出血が多いという報告がある191.また 44 アリルを持 つ群では脳梗塞, 脳出血ともに多く認められ, e3/e3 型は脳血管疾患に対して保護的に働くとされてい る ${ }^{10\}}$. 他に, リポ蛋白リパーゼ (LPL) 遺伝子の Ser447 stop 変異 $(C \rightarrow G)$ において, Gアリルの存在が脳血管 
疾患のリスク有意に下げると報告されている゙．

d. 血栓形成に関する遺伝因子

(1)グリコプロテイン（GP）遺伝子多型

GP Ib $\alpha$ には Kozak T/C 多型, Thr145 Met 多型が存 在し, Kozak のCアリルは脳卒中群で高頻度に認めら れ，また145Metアリルも脳卒中群で高頻度に認めら れている ${ }^{12)}$ 。さらに $\mathrm{GpIa} / \mathrm{II}$ aの Cys807Thr多型に ついても, Thr807アリルが50 歳以下の若年者の脳卒 中のリスクと関連するとの報告がある ${ }^{137}$.

(2)カテプシン G (CTSG) 遗伝子

血小板機能を活性化させるカテプシン Gの Asn125

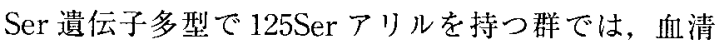
フィブリノーゲン濃度が有意に高值で，脳卒中の頻度 が高いことが報告されている年．

(3) PAI (Plasminogen activator inhibitor) -1 遗伝子

線溶系蛋白 PAI-1 遺伝子には $4 \mathrm{G} / 5 \mathrm{G}$ 多型がある. 52 歲以上の女性において $4 \mathrm{G} / 4 \mathrm{G}$ 型を持つ群は， $5 \mathrm{G} / 5 \mathrm{G}$ 型を持つ群に比し脳梗塞による死亡のリスクが有意に 低率であるとの報告がある ${ }^{15}$.

(5)第 V 因子 遺伝子，プロトロンビン遺伝子

第 V 因子 G1691A 多型の 1691A アリルとプロトロ ンビン遺伝子 G20210A 多型の 20210A アリルは脸梗 塞の独立した因子であると報告されている

(6) $\beta$-フィブリノーゲン遺伝子

队-フィブリノーゲン遺伝子には，プロモーター領域 に Gly455Ala，Gly854Ala多型など5つの遺伝子多型 が在る. Gly455Ala 多型の Ala アリルの頻度は脳梗塞 群で有意に高いという報告がある17゙。また Gly455Ala 多型, Gly854Ala多型ともにAlaアリルを持つものは 血清 fibrinogen 濃度が高く, 脳梗塞との関連が示唆さ れている18.

(7)グリコプロテイン (GP) II a/III a 遺伝子

フイブリノーゲンと von Willebrand 因子の膜受容 体であるグリコプロティン II a/III a の PI A1/A2 遺 伝子多型において，欧米白人でA2アリルを有する群 では脳梗塞が高率に認められているという ${ }^{19}$.

e. 酸化ストレスに関する遺伝因子

(1) 22 phox 遺伝子

血管における活性酸素の発生源としてNADH/ NADPH オキシダーゼが重要な役割を果たしている が, その活性調節に関与している p22phox 遺伝子のC $242 \mathrm{~T}$ 多型で CC 型を有する群では有意に脳卒中のリ スクが高いと言われている201.

(2)パラオキソナーゼ (Paraoxonase, PON1) 遺伝子
ヒトパラオキソナーゼ（PON1）は HDLに結合して 存在し, 抗動脈硬化作用を発揮する. GlnQ192ArgR 多型で Argアリルを有する群では脸卒中の頻度が 有意に高いという報告がなされている211.

f. その他の遺伝因子

(1)メチレンテトラヒドロ葉酸リダクターゼ (MTHFR) 遗伝子

MTHFR 遺伝子の多型はIfl 中ホモシステイン濃度 と関連があり, 動脈硬化性病変や血栓性病変の独立し た危険因子である。近年, MTHFRの C677T 多型にお いて，TT 型が脳卒中の有意なリスクになるという報 告がなされた222. しかし我々の知見では脳血管疾患と の関連は明らかでなかっだ23.

(2)エンドグリン（Endoglin）遺伝子

エンドグリンは形質転換成長因子 TGF- $\beta$ の結合蛋 白である、エンドグリン遺伝子の第 7 エタソンに $6 \mathrm{bp}$ の㨂入/欠損を示す insertion/deletion (I/D) 多型が存 在するが, I/I 型では脳出血のリスクが有意に高いとい う報告がある ${ }^{24)}$.

\section{おわりに}

これまで述べてきたように，高血圧と脳卒中のリス ク遺伝子の解析が進みつつある. 今後, 脳卒中の遺伝 素因が明らかになれば，これに契煙などの古典的りス クファクターを加えて総合的に将来の危険性を予測す ることが可能となり，脳疾患のオーダーメイド医療が 確立してゆくものと期待されている.

\section{文献}

1) Higaki J, et al : Hypertension and genes. Int Med $40: 144-147,2001$

2) Sato N, et al: Association of variants in critical core promotor element of angiotensinogen gene with increased risk of essential hypertension in Japanese. Hypertension $30: 321-325,1997$

3）檜垣實男, 勝谷友宏, 荻原俊男：人類の進化と高血 圧の遺伝䋕因。内分泌・糖尿病科 $10: 418-424$. 2000

4) Takami S, et al : Gene polymorphism of the reninangiotensin system associates with risk for lacunar infarction : The Ohasama study. Am J Hypertens 13: 121-127, 2000

5) Margaglione $M$, et al : Deletion polymorphism in the angiotensin-converting enzyme gene in patients with a history of ischmic stroke. Arterioscler Thromb Vasc Biol 16 : 304-309, 1996 
6) Nakata $Y$, et al : Polymorphism of angiotensin converting enzyme, angiotensinogen, and apolipoprotein $E$ genes in a Japanese population with cerebrovascular disease. Am J Hypertens 10 : 13911395, 1997

7) Takami S, et al : Gene polymorphism of the reninangiotensin system associates with risk for lacunar infarction. Am J Hypertens $13: 121-127$, 2000

8) Elbaz A. et al: Association between the Glu298 Asp polymorphism in the endothelial constitutive nitric oxide synthase gene and brain infarction. The GENIC Investigators. Stroke $31: 1634-1639$, 2000

9) Kokubo Y, et al : Age-dependent association of apolipoprotein $\mathrm{E}$ genotypes with stroke subtypes in a Japanese rural population. Stroke 31 : 12991306,2000

10) Coudrec R, et al : Prevalence of apolipoprotein $E$ phenotypes in ischemic cerebrovascular disease. A case control study. Stroke 24:661-664, 1993

11) Shimo-Nakanishi $Y$, et al : Polymorphism of the lipoprotein lipase gene and risk of atherothrombotic cerebral infarction in the Japanese. Stroke $32: 1481-1486,2001$

12) Baker RI, et al : Platelet glycoprotein Ibalpha Kozak polymorphism is associated with an increased risk of ischemic stroke. Blood 98:36-40, 2001

13) Carlsson LE, et al : The alpha 2 gene coding sequence T807/A873 of the platelet collagen receptor integrin alpha 2 beta 1 might be a genetic risk factor for the development of stroke in younger patients. Blood $93: 3583-3586,1999$

14) Hermann SM, et al: Characterization of polymorphic structure of cathepsin $\mathrm{G}$ gene : role in cardiovascular and cerebrovascular diseases. Arterioscler Thromb Vasc Biol 21 : 1538-1543, 2001

15) Roest $M$, et al : Plasminogen activator inhibitor $4 G$ polymorphism is associated with decreased risk of cerebrovascular mortality in older women. Circulation $101: 67-70,2000$

16) Akar N, et al : Factor V 1691 G-A, prothorombin $20210 \mathrm{G}-\mathrm{A}$, and methylenetetrahydrofolate reductase $677 \mathrm{C}$-T variants in Turkish children with cerebral infarct. J Child Neurol 14 : 749-751, 1999

17) Nishiuma $S$, et al : Genetic variation in the promoter region of the beta-fibrinogen gene is associated with ischemic stroke in a Japanese population. Blood Coagul Fibrinolysis $9: 373-379,1998$.

18) van't Hooft FM, et al: Two common. functional polymorphisms in the promoter region of the beta-fibrinogen gene contribute to regulation of plasma fibrinogen concentration. Arterioscler Thromb Vasc Biol 19:3063-3070, 1999

19) Wagner $K R$, et al : Platelet glycoprotein receptor III a polymorphism P1A2 and ischemic stroke risk : the Stroke Prevention in Young Women Study. Stroke $29: 581-585,1998$

20) Ito D, et al : C242T polymorphism of NADPH oxidase p22PHOX gene and ischemic cerebrovascular disease in the Japanese population. Stroke 31 : $936-939,2000$

21) Imai $Y$, et al : Evidence for association between paraoxonase PON 1 polymorphisms and atherosclerotic diseases. Atherosclerosis $149: 435-442$. 2000

22) Morita $\mathrm{H}$, et al : Methylenetetrahydrofolate reductase gene polymorphism and ischemic stroke in Japanese. Arterioscler Thromb Vasc Biol 18 : $1465-1469,1998$

23) Nakata $Y$, et al : Methylenetetrahydrofolate reductase gene polymorphism : relation to blood pressure and cerebrovascular disease. Am J Hypertens $11: 1019-1023,1998$

24) Alberts MJ, et al : Endoglin gene polymorphism as a risk factor for sporadic intracerebral hemorrage. Ann Neurol $41: 683-686,1997$ 


\title{
Abstract \\ Genetic epidemiology of hypertension and cerebrovascular disease
}

\author{
Jitsuo Higaki, M.D., Ken Sugimoto, M.D.*, Tomohiro Katsuya, M.D.* and Toshio Ogihara, M.D.* \\ 2nd Department of Internal Medicine, Ehime University Medical School \\ *Department of Geriatric Medicine, Postgraduate School of Medicine, Osaka University
}

The molecular understanding of the genes of cerebrovascular disease and hypertension may contribute to better development of new diagnosis and treatment. Under classical strategy, scientists have tried first to find a physiological phenomenon specific for essential hypertension, then to identify the protein underlying the physiological abnormality, and finally to clarify the causative gene which encoded the protein. On the other hand, under the reverse genetic approach, the correlation between hypertension and genetic abnormality is identified first, and then the pathogenesis is clarified-in reverse order. Therefore, it is not extraordinary for unexpected results to be obtained in the correlation between a gene and a disease, suggesting that this approach has a possibility to be a breakthrough in the chaos of the research of hypertension and cerebrovascular disease.

Key words : gene, hypertension, cerebrovascular disease, apoplexy

(Jpn J Stroke 24:513-518, 2002) 